\title{
The unsettled question of bronchodilator aerosol administration in mechanically ventilated patients
}

\author{
YVES LACASSE MD, LOUIS-PHILIPPE BOULET MD, NOËL LAMPRON MD \\ Centre de Pneumologie, Hôpital Laval and Université Laval, Ste-Foy, Québec
}

Y LACASSE, L-P Boulet, N LAMPRON. The unsettled question of bronchodilator aerosol administration in mechanically ventilated patients. Can Respir J 1996; 3(5):331-334.

Aerosols have gained wide acceptance over the past 10 years for the treatment of obstructive diseases. However, much controversy still exists about their use and mode of administration in the setting of intensive care units for intubated patients. The current literature was reviewed addressing the following question: In intubated and mechanically ventilated patients with airway obstruction, should bronchodilator aerosols be delivered through a metered-dose inhaler (MDI) or a nebulizer in order to reduce complications associated with high airway resistance? Most often investigators have examined, in uncontrolled trials, the effect of bronchodilator aerosols administered either through MDIs or nebulizers in lung models, or in populations of patients with heterogeneous conditions. An extremely wide range of bronchodilator dosages has been studied. Clinical outcomes have consisted of either drug deposition or lung mechanical characteristics. Only three randomized controlled trials comparing the effects of bronchodilator aerosols delivered through a nebulizer to those delivered through an MDI have been published, without clearly demonstrating the superiority of one mode of administration over the other. There is a need for randomized controlled trials comparing the effect of bronchodilator aerosols delivered through nebulizer versus MDI on the incidence of ventilator-associated complications in mechanically ventilated patients with obstructive lung diseases.

Key Words: Airway obstruction, Metered-dose inhaler, Nebulizer

\section{La question non résolue de l'administration des bronchodilatateurs en aérosols chez les pa- tients ventilés mécaniquement}

RÉSUMÉ : Bien que depuis plus de dix ans, les aérosols soient largement acceptés dans le traitement des maladies pulmonaires obstructives, leur utilisation ainsi que leur mode d'administration aux soins intensifs chez les patients intubés demeurent controversés. Nous avons revu la littérature actuelle concernant la question suivante: « Chez les patients souffrant d'obstruction bronchique intubés et ventilés mécaniquement, devrait-on administrer les aérosols de bronchodilatateurs via un aérosol-doseur ou un nébuliseur dans le but de réduire les complications reliées à l'augmentation de la résistance des voies aériennes? » Le plus souvent, des études sans groupe témoin évaluant l'effet des 
bronchodilatateurs en aérosols administrés par aérosoldoseurs ou nébuliseurs ont été effectuées sur divers modèles pulmonaires ou chez des populations hétérogènes de patients. Des doses extrêmement variées de bronchodilatateurs ont été étudiées. Enfin, les variables à l'étude ont consisté en une mesure de la déposition pulmonaire du médicament ou de paramètres mécaniques. Seulement trois essais cliniques randomisés comparant les effets des bron- chodilatateurs en aérosols administrés par aérosol-doseurs ou par nébuliseurs ont été publiés, aucun d'entre eux n'ayant pu démontrer clairement la supériorité d'un mode d'administration par rapport à l'autre. Des essais cliniques randomisés comparant l'effet des aérosols de bronchodilatateurs administrés par aérosol-doseur ou par nébuliseur sur l'incidence des complications reliées à la ventilation mécanique chez des patients ventilés atteints de maladie obstructive sont nécessaires.
$\mathrm{I}_{\mathrm{m}}^{\mathrm{n}}$ n 1995, the respiratory therapists of the Centre de Pneumologie, Ste-Foy, Quebec delivered 6000 bronchodilator aerosol treatments to patients receiving mechanical ventilation. These treatments were evenly distributed between nebulization and administration by a metered-dose inhaler (MDI). Although aerosols have gained wide acceptance over the past 10 years for the treatment of obstructive diseases (1), much controversy still exists about their use and mode of administration in the setting of intensive care units for intubated patients (2).

In an effort to determine which of the two administration options to adopt, we reviewed the current literature on this specific question: In intubated and mechanically ventilated patients with airway obstruction, should bronchodilator aerosols be delivered through MDI or nebulizer in order to reduce complications of high airway resistance?

At least three overviews have addressed the issue of aerosol delivery to intubated patients (3-5). All are broad narrative reviews based on information retrieved from unspecified searching methods. The merit of the most recently published review (5) was to summarize a considerable amount of information in a tabular form. Our own literature search from 1984 to 1995 in MEDLINE using 'aerosols' and 'mechanical ventilation' as search terms provided additional relevant papers published thereafter (6-11), reflecting the continuing interest in this question. We have been struck, however, by the heterogeneity of the studies and the paucity of trials that provide direct evidence to answer this question best. By direct evidence, we mean randomized controlled trials (methodology) comparing the effects of bronchodilator aerosols delivered through a nebulizer with those delivered through an MDI (intervention) in mechanically ventilated patients with obstructive disease (population), with the aim of reducing complications related to high airway resistance (outcome). Thus, these different components of the question will be examined in order to evaluate the strength of the available evidence.

\section{POPULATION}

Laboratory studies of aerosol deposition in lung models (11-14) have significantly contributed to the technical development of aerosol administration in mechanically ventilated patients. However, we may recognize the following limitations: first, most lung models ignore anatomical, physiological, pathological and other technical factors determining the airway delivery of aerosols; second, in vitro aerosol deposi- tion at the extremity of the endotracheal tube does not necessarily imply in vivo action of the drug; and third, laboratory studies in lung models tend to overestimate in vitro delivery of aerosolized solutions (15). Thus, such studies can offer only indirect evidence that one delivery method is superior to the other when used in clinical practice.

Study populations in uncontrolled studies or clinical trials of aerosol-generator devices have been remarkably heterogeneous and the number of subjects limited. In addition to patients with exacerbation of chronic obstructive pulmonary disease (COPD) or asthma, these populations have included patients with cardiogenic pulmonary edema, Guillain-Barré syndrome (16), adult respiratory distress syndrome, bronchogenic carcinoma (17), pulmonary embolism (18), kyphoscoliosis and muscular dystrophy (7); for these conditions, the need for bronchodilator therapy is only empirical. It should be stressed, however, that bronchodilators in mechanically ventilated patients with COPD have never been shown to alter any clinical outcome (19). In at least one study, all patients were receiving prolonged mechanical ventilation via tracheostomy (7). Consequently, whatever the outcome (aerosol deposition or change in lung mechanics), the generalizability of most results seems to be questionable on at least two scores. First, when aerosol deposition is measured, distribution of ventilation in patients with any of these conditions is likely to differ from that in patients with asthma or COPD. Second, response to bronchodilators in patients with nonobstructive pulmonary disease is generally not expected, which limits the validity of lung mechanics as an outcome measure.

\section{INTERVENTION}

Also of concern were the tremendous dissimilarities among the various studies' drug regimens and dosages, as well as their techniques of administration for both nebulizers and MDIs. In studies that measured aerosol deposition, solutions of radiolabelled diethylenetriamine pentaacetic acid (DTPA) (16), serum albumin $(7,20)$ and fenoterol $(6,17)$ were used. The effects of salbutamol $(9,10,18,21,22)$, fenoterol $(6,17)$, metaproterenol (16) and ipratropium bromide $(8,21)$ have been investigated. When delivered by nebulizer, doses of salbutamol ranged from $2.5 \mathrm{mg}$ (22) to $15 \mathrm{mg}$ (18); when delivered by MDI, doses of salbutamol ranged from $200 \mu \mathrm{g}$ (two puffs) (21) to $9 \mathrm{mg}$ (100 puffs) (18). No clear dose-response effect was observed across studies; an improvement in lung mechanics was obtained with the lowest 
administered dose of salbutamol (21), whereas no effect followed the administration of the highest dose of the same drug (18). Some authors have also suggested that dosage should be titrated against the physiological effects (5). However, to do so, clinicians should be able to rely on simple, valid and sensitive physiological measures.

Detailed descriptions of nebulizer, nebulizer position, diluent volume, MDI adapters, spacer, endotracheal tube, ventilator and ventilatory parameters have often been lacking. Yet, these conditions have been shown to influence drug deposition in both lung models (13) and patients (6).

\section{OUTCOME}

The usual methods for assessing airway deposition of drugs are observation of physiological changes in lung mechanics and nuclear scanning of labelled medication (23). The concentration of salbutamol at the distal tip of the endotracheal tube has also been measured by spectrophotometric technique in one study using a lung model (14). However, as mentioned above, aerosol deposition may provide only indirect evidence of the effectiveness of the drug. Once the drug has reached the site of action, the final response surely depends, among other factors, on receptor distribution (24) and drug interactions.

Physiological responses thus provide the most direct means of determining the efficacy of aerosolized agents. However, the choice of the most appropriate outcomes has raised some controversies. Peak pressure $(8,10,16-18,21)$, expiratory flow rate $(16,22)$, airway resistance $(8,16)$, plateau pressure $(8,10,18,21)$, resistive pressure $(8,18,21)$, intrinsic positive end-expiratory pressure (PEEP) $(10,21)$ and compliance of the respiratory system (8) have all been used as measures of outcome. The contribution of the endotracheal tube, however, has seldom been taken into account in estimating pressure changes (25). Even if reduction of peak pressure and intrinsic PEEP have been found most valuable as evidence of bronchodilator-induced changes in lung function during controlled mechanical ventilation (26), Fuller and colleagues (17) appropriately pointed out that patients receiving bronchodilators in an intensive care setting may have only minimally reversible airflow obstruction during the exacerbation of their disease. Furthermore, no information exists about the real efficacy of bronchodilation in reducing ventilator-associated complications (barotrauma and nosocomial infections) (27) and duration of ventilatory support, which could be considered highly relevant outcomes.

\section{METHODOLOGY}

Among full reports (excluding abstracts) of randomized trials of nebulizer versus MDI to deliver bronchodilator aerosols in mechanically ventilated patients, only three trials were found that directly addressed this review's initial question: one randomized controlled trial with parallel groups (17) and two crossover trials $(18,22)$. Fuller et al (17) compared the deposition, as well as the physiological effect, of radiolabelled fenoterol when it was delivered either from an MDI coupled to a holding chamber or from a jet nebulizer in 21 ventilator-dependent patients. Sixteen patients (seven receiving fenoterol by MDI and nine receiving the drug by jet nebulizer) were accounted for in the final analysis. Eight suffered from chronic airflow limitation. Even though drug deposition was significantly greater in the MDI group, peak inspiratory pressure did not change significantly from baseline values in either group, clearly demonstrating that radioactivity deposition correlates poorly with physiological outcomes.

In a randomized crossover trial, Manthous et al (18) investigated the effect of up to $15 \mathrm{mg}$ of salbutamol delivered by nebulizer versus up to 100 puffs of the same drug delivered by MDI. The MDI adapter was attached directly to the endotracheal tube, without any spacer. No change in resistive pressure was observed in the MDI group, whereas a significant reduction was observed with only $2.5 \mathrm{mg}$ of salbutamol. The importance of the use of a spacer device was later acknowledged by the same group (9). Finally, in a randomized crossover trial including 18 intubated patients with airway obstruction, Gay et al (22) found that $270 \mu \mathrm{g}$ of salbutamol from an MDI and $2.5 \mathrm{mg}$ of salbutamol delivered through a nebulizer were equally effective in increasing passive expiratory flow rate. Both systems were, however, only briefly described.

We must recognize the paucity of direct evidence supporting the conclusion that MDIs are more effective than nebulizers in delivering bronchodilator aerosols to intubated, mechanically ventilated patients with airway obstruction. However, this observation should probably not discourage the use of the MDI/spacer to deliver bronchodilator aerosols in an intensive care setting - in the absence of evidence favouring superiority of nebulizers over MDIs, financial considerations $(3,17)$ might prompt clinicians to adopt the latter. However, randomized controlled trials are clearly warranted to compare the effect of bronchodilator aerosols delivered through nebulizer versus MDI in mechanically ventilated patients with obstructive lung diseases in order to improve pulmonary gas exchange and to reduce ventilator-associated complications and duration of ventilatory support.

\section{REFERENCES}

1. Newhouse MT, Dolovich MB. Control of asthma by aerosols. N Engl J Med 1986;315:870-3.

2. Newhouse MT, Fuller HD. Rose is a rose is a rose? Aerosol therapy in ventilated patients: nebulizers versus MDI - a continuing controversy. Am Rev Respir Dis 1993;148:1444-6.

3. Hess D. How should bronchodilators be administered to patients on ventilators? Respir Care 1991;36:377-94.

4. Reading PM, St John RE. Aerosolized therapy for ventilator-assisted patients. Crit Care Pharm 1993;5:271-80.

5. Manthous CA, Hall JB. Administration of therapeutic aerosols to mechanically ventilated patients. Chest 1994;106:560-71.

6. Fuller HD, Dolovich MB, Turpie FH, Newhouse MT. Efficiency of bronchodilator aerosol delivery to the lungs from the metered dose inhaler in mechanically ventilated patients - a study comparing four different actuator devices. Chest 1994;105:214-8.

7. O'Riordan TG, Palmer LB, Smaldone G. Aerosol deposition in mechanically ventilated patients - optimizing nebulizer delivery. Am J Respir Crit Care Med 1994;149:214-9.

8. Yang SC, Yang SP, Lee TS. Nebulized ipratropium bromide in ventilator-assisted patients with chronic bronchitis. Chest 1994;105:1511-5.

9. Manthous CA, Chatila W, Schmidt GA, Hall JB. Treatment of 
bronchospasm by metered-dose inhaler albuterol in mechanically ventilated patients. Chest 1995;107:210-3.

10. Dhand R, Jubran A, Tobin MJ. Bronchodilator delivery by metered-dose inhaler in ventilator-supported patients. Am J Respir Crit Care Med 1995; 151:1827-33.

11. Harvey CJ, O’Doherty MJ, Page CJ, Thomas SHL, Nunan TO, Treacher DF. Effect of a spacer on pulmonary aerosol deposition from a jet nebuliser during mechanical ventilation. Thorax 1995;50:50-3.

12. O'Riordan TG, Greco MJ, Perry RJ, Smaldone GC. Nebulizer function during mechanical ventilation. Am Rev Respir Dis 1992;124:1117-22.

13. O’Doherty MJ, Thomas SHL, Page CG, Treacher DF, Nunan TO. Delivery of a nebulized aerosol to a lung model during mechanical ventilation - effect of ventilator settings and nebulizer type, position, and volume of fill. Am Rev Respir Dis 1992;146:383-8.

14. Rau JL, Harwood RJ, Groff JL. Evaluation of a reservoir device for metered-dose bronchodilator delivery to intubated adults - an in vitro study. Chest 1992;102:924-30.

15. Fuller HD, Dolovich MB, Chambers C, Newhouse MT. Aerosol delivery during mechanical ventilation: a predictive in-vitro lung model. J Aerosol Med 1992;5:251-9.

16. MacIntyre NR, Silver RM, Miller CW, Schuler F, Coleman E. Aerosol delivery in intubated, mechanically ventilated patients. Crit Care Med $1985 ; 13: 81-4$

17. Fuller HD, Dolovich MB, Posmituck G, Wong Pack W, Newhouse MT. Pressurized aerosol versus jet aerosol delivery to mechanically ventilated patients - comparison of dose to the lungs. Am Rev Respir Dis 1990;141:440-4.

18. Manthous CA, Hall JB, Schmidt GA, Wood LDH. Metered-dose inhaler versus nebulized albuterol in mechanically ventilated patients. Am Rev Respir Dis 1993;148:1567-70.

19. Derenne JP, Fleury B, Pariente R. Acute respiratory failure of chronic obstructive pulmonary disease. Am Rev Respir Dis 1988;138:1006-33.

20. Thomas SHL, O’Doherty MJ, Fidler HM, Page CJ, Treacher DF, Nunan TO. Pulmonary deposition of a nebulised aerosol during mechanical ventilation. Thorax 1993;48:154-9.

21. Fernandez A, Lazaro A, Garcia A, Aragon C, Cerda E. Bronchodilators in patients with chronic obstructive pulmonary disease on mechanical ventilation - utilization of metered-dose inhalers. Am Rev Respir Dis 1990;141:164-8.

22. Gay PC, Patel HG, Nelson SB, Gilles B, Hubmayr RD. Metered dose inhalers for bronchodilator delivery in intubated, mechanically ventilated patients. Chest 1991;99:66-71.

23. Rebuck AS, Braude A. Assessment of drug disposition in the lung. Drugs 1984;28:544-53.

24. Barnes PJ, Basbaum CB, Nadel JA. Autoradiographic localization of autonomic receptors in airway smooth muscle - marked differences between large and small airways. Am Rev Respir Dis 1983;127:758-62.

25. Wright PE, Marini JJ, Bernard GR. In vitro versus in vivo comparison of endotracheal tube airflow resistance. Am Rev Respir Dis 1989;140:10-6.

26. Gay PC, Rodarte JR, Tayyab M, Hubmayr RD. Evaluation of bronchodilator responsiveness in mechanically ventilated patients. Am Rev Respir Dis 1987;136:880-5.

27. Craven DE, Lichtenberg DA, Goularte TA, Make BJ, McCabe WR. Contaminated medication nebulizers in mechanical ventilator circuits source of bacterial aerosols. Am J Med 1984;77:834-8. 


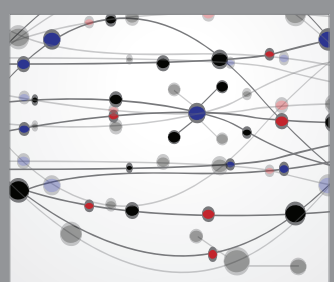

The Scientific World Journal
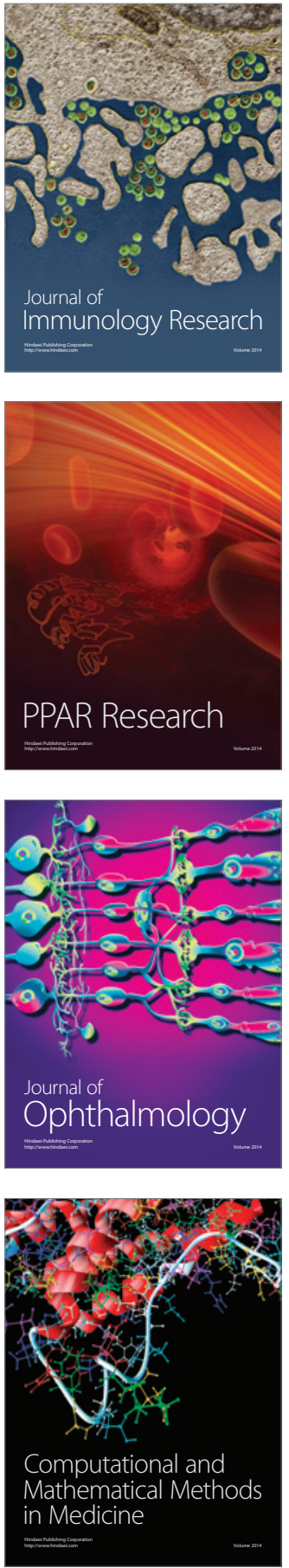

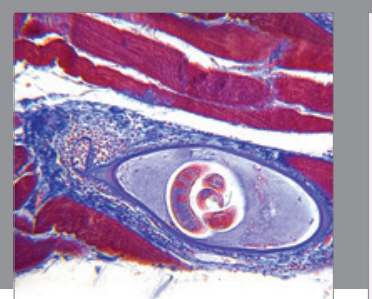

Gastroenterology Research and Practice

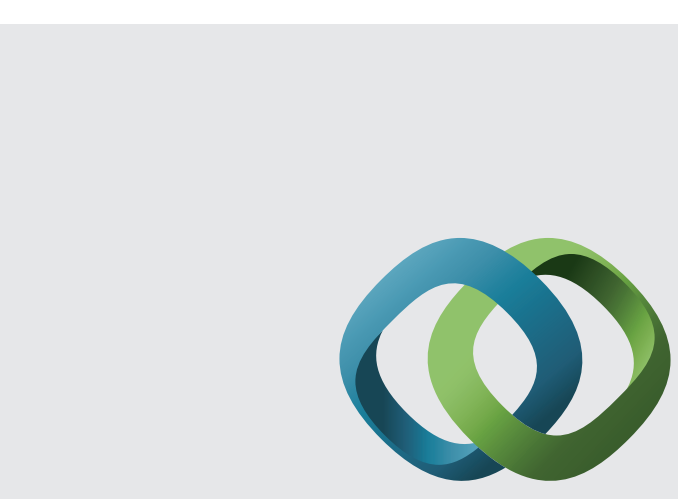

\section{Hindawi}

Submit your manuscripts at

http://www.hindawi.com
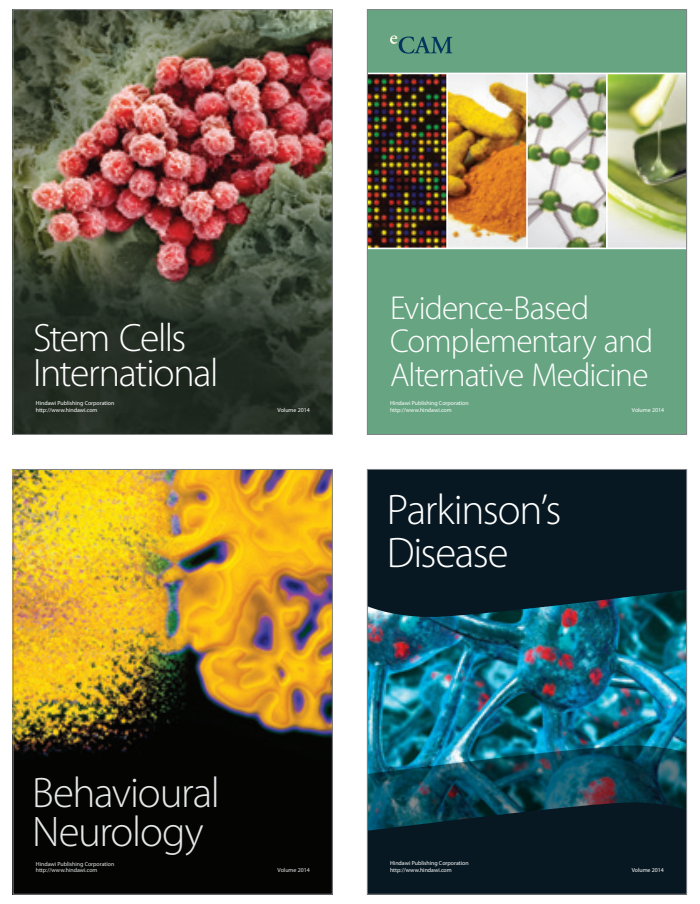
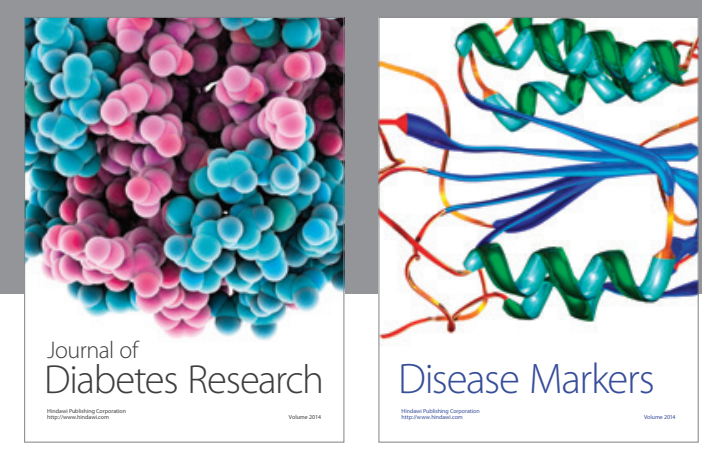

Disease Markers
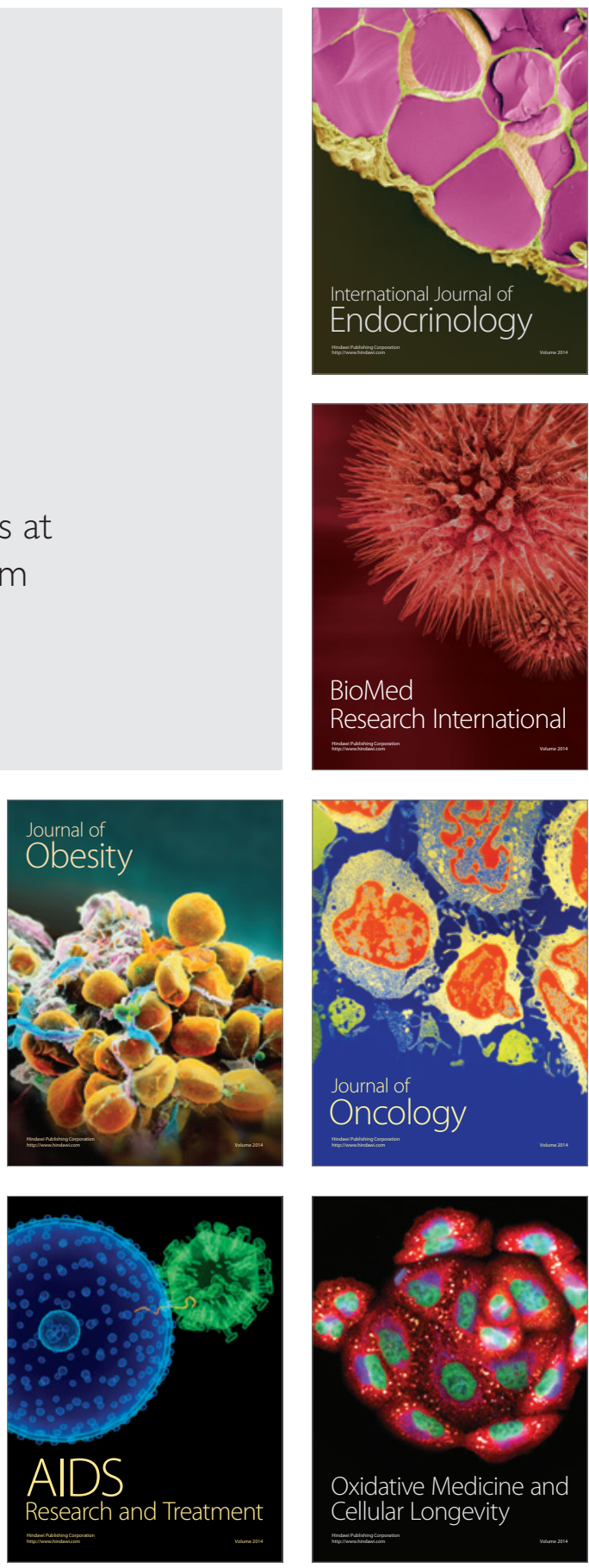